\title{
Peramalan Jumlah Wisatawan Mancanegara Yang Datang Ke Sumatera Utara dengan Fuzzy Time Series
}

\author{
Didi Febrian $^{1, a)}$, Dinda Kartika ${ }^{2, b)}$, Debora Agnes Jessica Nainggolan ${ }^{3, c)}$ \\ 1,2,3 Jurusan Matematika, FMIPA, Universitas Negeri Medan, Medan \\ a)email : febrian.didi@unimed.ac.id \\ b)email : dindakartika@unimed.ac.id \\ c)email : agnesnainggolan.math@gmail.com
}

\begin{abstract}
Abstrak
Pariwisata merupakan sektor ekonomi yang secara langsung menyentuh dan melibatkan masyarakat. Akibatnya, perubahan sektor pariwisata akan berdampak langsung bagi perekonomian masyarakat. Berdasarkan data BPS, jumlah wisatawan mancanegara yang datang ke Sumatera Utara berfluktuasi, artinya jumlahnya dapat meningkat maupun menurun setiap bulan dan tahun. Berfluktuasinya perubahan jumlah wisatawan mancanegara ini berdampak bagi pelaku pariwisata. Oleh sebab itu, diperlukan suatu cara untuk meramalkan perkiraan jumlah wisatawan mancanegara yang datang ke Sumatera Utara. Pada Penelitian ini, peneliti menggunakan metode Fuzzy Time Series Markov Chain Model. Hasil peramalan tergantung oleh banyak partisi (banyak interval) yang dilakukan. Untuk menentukan banyak interval, peneliti menggunakan dua rumus yaitu rumus Sturges dan average based length. Penelitian ini menggunakan 108 data sekunder, yaitu jumlah wisatawan yang datang ke Sumatera Utara mulai Januari 2010 sampai Desember 2018 yang diambil dari BPS Sumatera Utara. Data dikelompokkan menjadi Data Training sebanyak 85 data dan data uji 23 data. Penggunaan rumus Sturges menghasilkan banyak interval 7 dan rumus average based length menghasilkan banyak interval 20. Akurasi peramalan untuk banyak interval 7 lebih akurat daripada banyak interval 20 . Hal ini ditandai nilai MAPE $6.66 \%$ untuk banyak interval 7 dan $9.87 \%$ untuk banyak interval 20. Hasil peramalan untuk bulan Januari 2019 adalah 21594,0625.
\end{abstract}

Kata Kunci : Pariwisata, Peramalan, Fuzzy Time Series, Markov Chain

\begin{abstract}
Tourism is an economic sector that directly touches and involves the community. As a result, changes in the tourism sector will have a direct impact on the community's economy. Based on BPS data, the number of foreign tourists who come to North Sumatra fluctuates, meaning that the number can increase or decrease every month and year. This fluctuating change in the number of foreign tourists has an impact on tourism actors. Therefore, we need a way to predict the estimated number of foreign tourists who come to North Sumatra. In this study, researchers used the Fuzzy Time Series Markov Chain Model method. Forecasting results depend on the number of partitions (many intervals) performed. To determine the number of intervals, the researcher uses two formulas, namely the Sturges formula and the average based length. This study uses 108 secondary data, namely the number of tourists who come to North Sumatra from January 2010 to December 2018 taken from the BPS North Sumatra. The data are grouped into training data with 85 data and 23 test data. The use of the Sturges formula produces many 7 intervals and the average based length formula produces 20 intervals. Forecasting accuracy for many 7 intervals is more accurate than many 20 intervals. This is indicated by MAPE values of $6.66 \%$ for many 7 intervals and $9.87 \%$ for many 20 intervals. Results the forecast for January 2019 is 21594.0625
\end{abstract}

Keywords: Tourism, Forecasting, Fuzzy Time Series, Markov Chain 


\section{Pendahuluan}

Pariwisata sebagai salah satu sektor perekonomian nasional merupakan sektor ekonomi yang secara langsung menyentuh dan melibatkan masyarakat. Menurut data BPS dan kementerian Perindustrian, Jasa Pariwisata khususnya wisatawan mancanegara menduduki posisi 3 besar sebagai penyumbang devisa terbesar di Indonesia. Pariwisata memberikan sumbangan terhadap penerimaan devisa, penciptaan lapangan kerja, memperluas kesempatan berusaha di sektor formal dan informal, peningkatan pendapatan pemerintah pusat dan daerah melalui berbagai pajak dan retribusi, peningkatan pendapatan masyarakat dan pemerataan pembangunan [1]. Oleh sebab itu, perhatian terhadap sektor pariwisata menjadi sesuatu yang sangat penting.

Sebagai salah satu provinsi terbesar di Indonesia, Sumatera Utara memiliki potensi pariwisata yang sangat besar. Hampir seluruh kota dan kabupaten di Sumatera Utara memiliki potensi pariwisata berupa wisata alam, budaya maupun kuliner yang dapat dikembangkan. Segala potensi yang dimiliki tersebut, selayaknya dapat menarik animo wisatawan, khususnya wisatawan mancanegara untuk datang ke Sumatera Utara. Berdasarkan data yang diperoleh dari BPS, jumlah wisatawan mancanegara yang berkunjung ke Sumatera Utara berfluktuasi, artinya jumlahnya dapat meningkat maupun menurun setiap bulan dan tahun. Berfluktuasinya perubahan jumlah wisatawan ini akan memberikan dampak bagi pelaku pariwisata. Peningkatan jumlah wisatawan yang tidak terduga akan membuat pelaku wisata sulit memberikan pelayan yang optimal bagi wisatawan. Bagi pemerintah, khususnya pemerintah daerah, berfluktuasinya jumlah wisatawan berpengaruh pada arah kebijakan yang akan diambil. Oleh sebab itu, diperlukan suatu cara untuk meramalkan perkiraan jumlah wisatawan, khususnya mancanegara yang datang.

Matematika sebagai bidang ilmu memiliki banyak peranan dalam menyelesaikan persoalan manusia. Salah satu bidang kajian dalam Matematika yang banyak digunakan adalah forecasting (peramalan). Peramalan adalah penggunaan teknik-teknik statistika dalam bentuk gambaran masa depan berdasarkan pengolahan angka-angka historis [2],[3],[4],[5]. Dengan kata lain, peramalan dalam Matematika adalah peramalan yang bersifat saintifik berdasarkan data-data terdahulu.

Penelitian tentang peramalan khususnya penelitian yang menggunakan data deret waktu (time series) telah banyak dilakukan. Data Time Series adalah data yang dikumpulkan dari waktu ke waktu yang menggambarkan perkembangan suatu kegiatan. Pada tahun 1993, Song \& Chissom [6] memperkenalkan sistem peramalan dengan metode fuzzy time series. Perbedaan antara time series dan fuzzy time series berada pada data yang digunakan dalam peramalan. Jika time series menggunakan data aktual maka fuzzy time series menggunakan data berupa himpunan fuzzy yang berasal dari data aktual.

Peramalan untuk memprediksi jumlah orang pada suatu kegiatan di masa datang menggunakan metode fuzzy time series telah banyak dilakukan. Metode fuzzy time series untuk meramalkan jumlah pendaftar di Universitas Alabama dari tahun ke tahun [7]. Jumlah kunjungan wisatawan di kota Batu diramalkan menggunakan metode Time Invariant Fuzzy Time Series [8]. Indeks Harga Saham Gabungan diramalkan dengan metode Fuzzy Time Series Markov Chain Model menyatakan bahwa akurasi metode tersebut cukup baik [9]. Akurasi peramalan yang sangat baik didapatkan saat mengimplementasikan metode Fuzzy Time Series Markov Chain Model dalam meramalkan harga emas [10]. Oleh sebab itu, peneliti tertarik menggunakan metode Fuzzy Time Series Markov Chain Model dalam meramalkan jumlah wisatawan mancanegara yang datang ke Sumatera Utara. 
Pada peramalan dengan metode fuzzy time series, penentuan banyak partisi pada himpunan semesta (banyak interval) sangat berpengaruh dalam akurasi peramalan. Oleh sebab itu, pemilihan banyak interval menjadi sesuatu yang penting. Pada penelitian ini, peneliti akan membandingkan akurasi peramalan dari banyak interval yang menggunakan rumus Sturges dengan rumus average based length. Akurasi peramalan dilihat dari nilai MAPE terkecil. Selanjutnya peneliti akan meramalkan jumlah wisatawan yang datang ke Sumatera Utara pada tahun 2019 menggunakan model yang memiliki MAPE terkecil.

\section{Metode}

Untuk memperoleh hasil penelitian yang baik, peneliti melakukan tahapan penelitian yang sistematis. Gambar 1 berikut menunjukan flowchart dari tahapan yang digunakan pada penelitian ini.

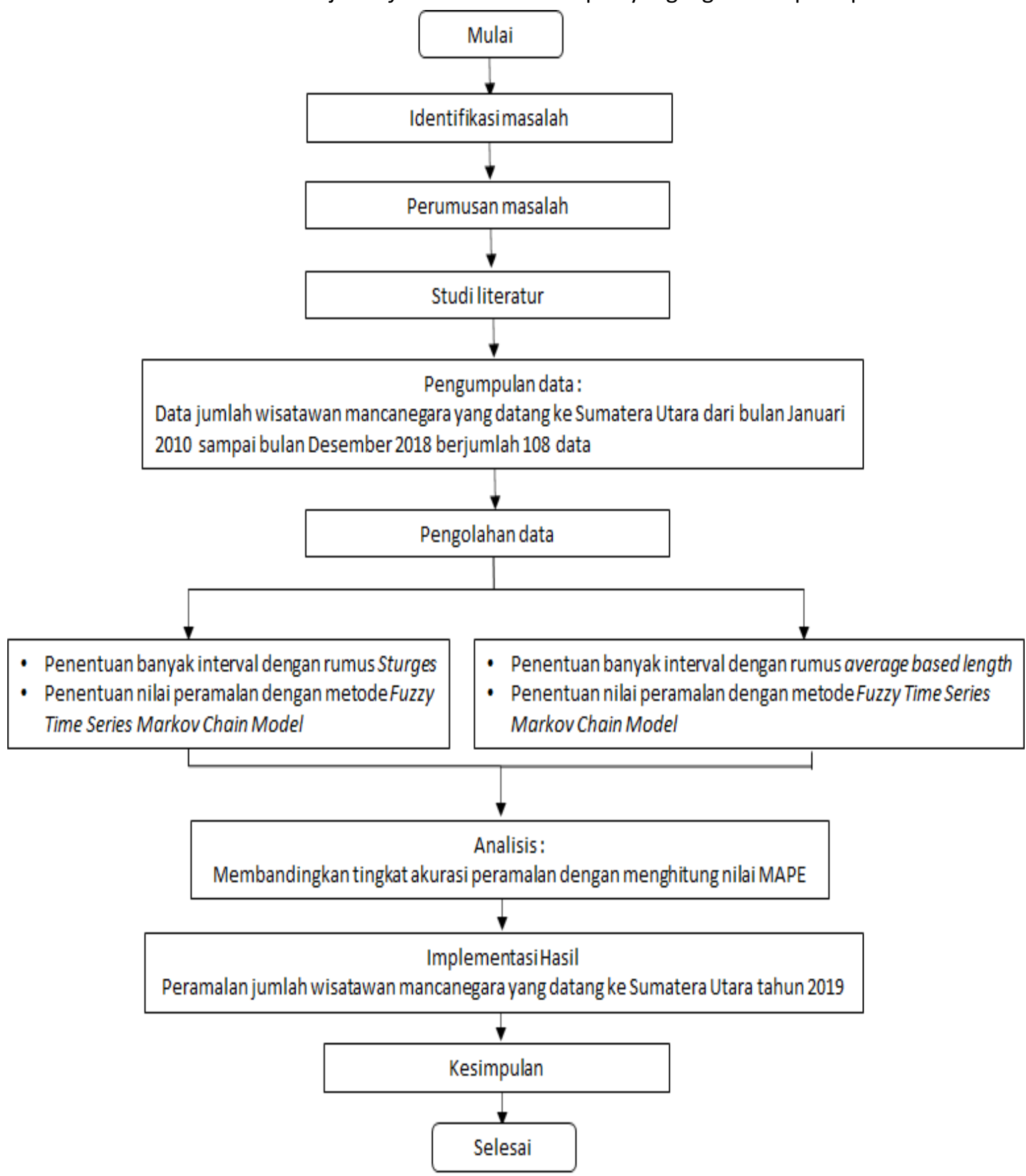

Gambar 1. Flowchart Penelitian 


\section{Fuzzy Time Series Markov Chain Model}

Metode Fuzzy Time Series Markov Chain pertama kali diperkenalkan oleh Tsaur [8] saat meramalkan nilai tukar mata uang Taiwan dengan dolar US. Untuk menggunakan metode ini, langkah-langkah yang dilakukan adalah sebagai berikut :

1) Membentuk himpunan semesta $U$ dari data.

2) Menghitung banyak dan panjang interval.

3) Membentuk Himpunan Fuzzy.

4) Fuzzifikasi Data Aktual

5) Menentukan Fuzzy Logic Relation (FLR) dan Fuzzy Logic Relations Group (FLRG)

6) Penentuan Model

7) Peramalan

8) Penyesuaian nilai ramalan.

9) Menentukan hasil peramalan akhir.

10)Menghitung akurasi hasil peramalan dengan menghitung nilai MAPE, yaitu

\section{Hasil dan Diskusi}

\section{Data Penelitian}

Pada penelitian ini, peneliti menggunakan data sekunder yang diambil langsung dari kantor Badan Pusat Statistik (BPS) Sumatera Utara. Data yang digunakan adalah data jumlah wisatawan mancanegara yang datang ke Sumatera Utara dari bulan Januari 2010 sampai bulan Desember 2018 berjumlah 108 data dengan jumlah berfluktuasi. Data terbesar terdapat pada bulan Desember 2014 sebesar 33017 dan data terkecil pada bulan Januari 2016 sebesar 13103 dengan nilai rata-rata 19974.9.

Dalam proses peramalan, peneliti membagi data menjadi dua bagian. Bagian pertama terdiri dari 85 data, yaitu data bulan Januari 2010 sampai dengan Januari 2017 sebagai data percobaan (data training) untuk mendapatkan model peramalan. Sedangkan bagian kedua terdiri dari 23 data, yaitu data bulan Februari 2017 sampai Desember 2018 sebagai data pengujian model (data uji). Untuk mempermudah perhitungan dalam pengolahan data, peneliti menggunakan Ms. Excel

\section{Pembentukan Model Peramalan Dengan Metode Fuzzy Time Series Markov Chain}

Langkah-langkah mendapatkan model peramalan dengan metode Fuzzy Time Series Markov Chain adalah sebagai berikut :

1) Membentuk Himpunan Semesta

Dari 85 data uji, diperoleh data terbesar adalah 33017 dan terkecil adalah 13103. Akibatnya diperoleh $D_{\max }=33017$ dan $D_{\min }=13103$. Untuk rumus Sturges dipilih $D_{1}=23$ dan $D_{2}=$ 27 sehingga diperoleh $U=[13103-23,33017+27]=[13080,33044]$. Sedangkan untuk rumus average based length dipilih $D_{1}=3$ dan $D_{2}=83$ sehingga diperoleh $U=[13103-$ $3,33017+83]=[13100,33100]$.

2) Menghitung banyak dan panjang interval.

Dengan rumus Sturges, banyak interval dapat diperoleh $n=1+3.333 \cdot \log \log (85)=$ 7.431 dibulatkan 7. Selanjutnya panjang interval diperoleh $l=\frac{33044-13080}{7}=2852$.

Dengan rumus average based length, diawali menghitung nilai-nilai mutlak selisih $D_{t}$ dan $D_{t-1}$, yaitu $\left|D_{t-1}-D_{t}\right|$. Selanjutnya dihitung rata-rata nilai mutlak selisih tersebut, diperoleh 2546.06. Kemudian rata-rata tersebut dibagi dua untuk mendapatkan panjang interval $(l)$, 
diperoleh 1273.03. Karena nilai 1273.03 berada pada basis 1000 maka panjang interval ditetapkan $l=1000$. Dari panjang interval tersebut, diperoleh banyak interval $n=$ $\frac{33100-13100}{1000}=20$.

3) Membentuk Himpunan Fuzzy

Berdasarkan banyak interval yang telah diperoleh, himpunan $U$ dipartisi menjadi beberapa bagian sama besar yaitu :

- $\quad$ Banyak interval 7 diperoleh :

$$
\begin{gathered}
u_{1}=[13080,15932], \text { nilai tengah } m_{1}=14506, \\
u_{2}=[15932,18784], \text { nilai tengah } m_{2}=17358, \\
\vdots \\
u_{7}=[30192,33044], \text { nilai tengah } m_{7}=31618
\end{gathered}
$$

Selanjutnya dapat didefinisikan himpunan fuzzy berikut :

$$
\begin{gathered}
A_{1}=\frac{1}{u_{1}}+\frac{0.5}{u_{2}}+\frac{0}{u_{3}}+\cdots+\frac{0}{u_{7}^{\prime}} \\
A_{2}=\frac{0.5}{u_{1}}+\frac{1}{u_{2}}+\frac{0.5}{u_{3}}+\frac{0}{u_{4}}+\cdots+\frac{0}{u_{7}} \\
A_{3}=\frac{0}{u_{1}}+\frac{0.5}{u_{2}}+\frac{1}{u_{3}}+\frac{0.5}{u_{4}}+\frac{0}{u_{5}}+\cdots+\frac{0}{u_{7}}, \\
\vdots \\
A_{7}=\frac{0}{u_{1}}+\frac{0}{u_{2}}+\frac{0}{u_{3}}+\cdots+\frac{0.5}{u_{6}}+\frac{1}{u_{7}} .
\end{gathered}
$$

- $\quad$ Banyak interval 20 diperoleh :

$$
\begin{gathered}
u_{1}=[13100,14100], \text { nilai tengah } m_{1}=13600, \\
u_{2}=[14100,15100], \text { nilai tengah } m_{2}=14600, \\
u_{3}=[15100,16100], \text { nilai tengah } m_{3}=15600, \\
\vdots \\
u_{19}=[31100,32100], \text { nilai tengah } m_{19}=31600, \\
u_{20}=[32100,33100], \text { nilai tengah } m_{20}=32600
\end{gathered}
$$

Kemudian himpunan fuzzy didefinisikan sebagai berikut :

$$
\begin{gathered}
A_{1}=\frac{1}{u_{1}}+\frac{0.5}{u_{2}}+\frac{0}{u_{3}}+\cdots+\frac{0}{u_{20}}, \\
A_{2}=\frac{0.5}{u_{1}}+\frac{1}{u_{2}}+\frac{0.5}{u_{3}}+\frac{0}{u_{4}}+\cdots+\frac{0}{u_{20}}, \\
A_{3}=\frac{0}{u_{1}}+\frac{0.5}{u_{2}}+\frac{1}{u_{3}}+\frac{0.5}{u_{4}}+\frac{0}{u_{5}}+\cdots+\frac{0}{u_{20}},
\end{gathered}
$$


KUBIK: Jurnal Publikasi Ilmiah Matematika

$$
A_{20}=\frac{0}{u_{1}}+\frac{0}{u_{2}}+\frac{0}{u_{3}}+\cdots+\frac{0.5}{u_{19}}+\frac{1}{u_{20}} .
$$

4) Fuzzikasi data aktual

Pada tahap ini, data aktual yang berupa besaran tegas diubah menjadi besaran fuzzy. Pengubahan ini dilakukan dengan cara melihat interval yang mengandung data aktual. Kemudian data aktual tersebut diubah menjadi himpunan fuzzy yang mengandung interval tersebut. Fuzzifikasi 85 data aktual sebagai data training dapat dilihat pada Tabel 1.

Tabel 1. Fuzzifikasi Data Aktual

\begin{tabular}{cccc}
\hline Bulan & $\begin{array}{c}\text { Data } \\
\text { Aktual }\end{array}$ & $\begin{array}{c}\text { Fuzzifikasi } \\
\text { Banyak } \\
\text { interval 7 }\end{array}$ & $\begin{array}{c}\text { Banyak } \\
\text { interval 20 }\end{array}$ \\
\hline Januari 2010 & 14067 & $\mathrm{~A} 1$ & $\mathrm{~A} 1$ \\
Februari & 15765 & $\mathrm{~A} 1$ & $\mathrm{~A} 3$ \\
Maret & 17038 & $\mathrm{~A} 2$ & $\mathrm{~A} 4$ \\
April & 15091 & $\mathrm{~A} 1$ & $\mathrm{~A} 2$ \\
$\vdots$ & $\vdots$ & $\vdots$ & $\vdots$ \\
Oktober & 23426 & $\mathrm{~A} 4$ & $\mathrm{~A} 11$ \\
2016 & 23650 & $\mathrm{~A} 4$ & $\mathrm{~A} 11$ \\
November & 28950 & $\mathrm{~A} 6$ & $\mathrm{~A} 16$ \\
Desember & 20554 & $\mathrm{~A} 3$ & $\mathrm{~A} 8$ \\
Januari 2017 & & &
\end{tabular}

5) Menentukan Fuzzy Logic Relation (FLR) dan Fuzzy Logic Relations Group (FLRG) Penentuan relasi logika fuzzy (FLR) dilakukan dengan menghubungkan antara setiap data dengan data berikutnya dalam bentuk himpunan fuzzy, $A_{j} \rightarrow A_{i}$ untuk $A_{j}$ adalah current state yaitu himpunan fuzzy di waktu $(t-1)$ dan $A_{i}$ adalah next state, yaitu himpunan fuzzy di waktu $t$. Perhatian pada bulan Februari 2010, diperoleh FLR $A_{1} \rightarrow A_{1}$ pada banyak interval 7 dan $A_{1} \rightarrow A_{3}$ pada banyak interval 20. Tabel 2. dapat dilihat seluruh FLR dan berapa kali FLR yang terjadi.

Tabel 2. Fuzzy Logic Relation (FLR)

\begin{tabular}{cccc}
\hline \multicolumn{2}{c}{ Banyak Interval 7 } & \multicolumn{2}{c}{ Banyak Interval 20 } \\
\hline FLR & $\begin{array}{c}\text { Banyak } \\
\text { Terjadi }\end{array}$ & FLR & Banyak Terjadi \\
$A_{1} \rightarrow A_{1}$ & 3 & $A_{1} \rightarrow A_{2}$ & 1 \\
$A_{1} \rightarrow A_{2}$ & 6 & $A_{1} \rightarrow A_{3}$ & 1 \\
$A_{1} \rightarrow A_{3}$ & 1 & $A_{1} \rightarrow A_{5}$ & 1 \\
$\vdots$ & $\vdots$ & $\vdots$ & $\vdots$ \\
$A_{7} \rightarrow A_{3}$ & 1 & $A_{6} \rightarrow A_{5}$ & 2 \\
$A_{7} \rightarrow A_{4}$ & 1 & $A_{6} \rightarrow A_{6}$ & 5 \\
& & $A_{6} \rightarrow A_{7}$ & 1 \\
& & $\vdots$ & $\vdots$ \\
& & $A_{18} \rightarrow A_{10}$ & 1 \\
& & $A_{20} \rightarrow A_{8}$ & 1 \\
\hline
\end{tabular}


Setelah seluruh FLR diperoleh, maka dapat dibentuk suatu grup Fuzzy Logic Relations Group (FLRG) yaitu pengelompokan dari FLR yang memiliki current state yang sama. FLRG dari data penelitian dapat dilihat pada Tabel 3

Tabel 3. Fuzzy Logic Relations Group (FLRG)

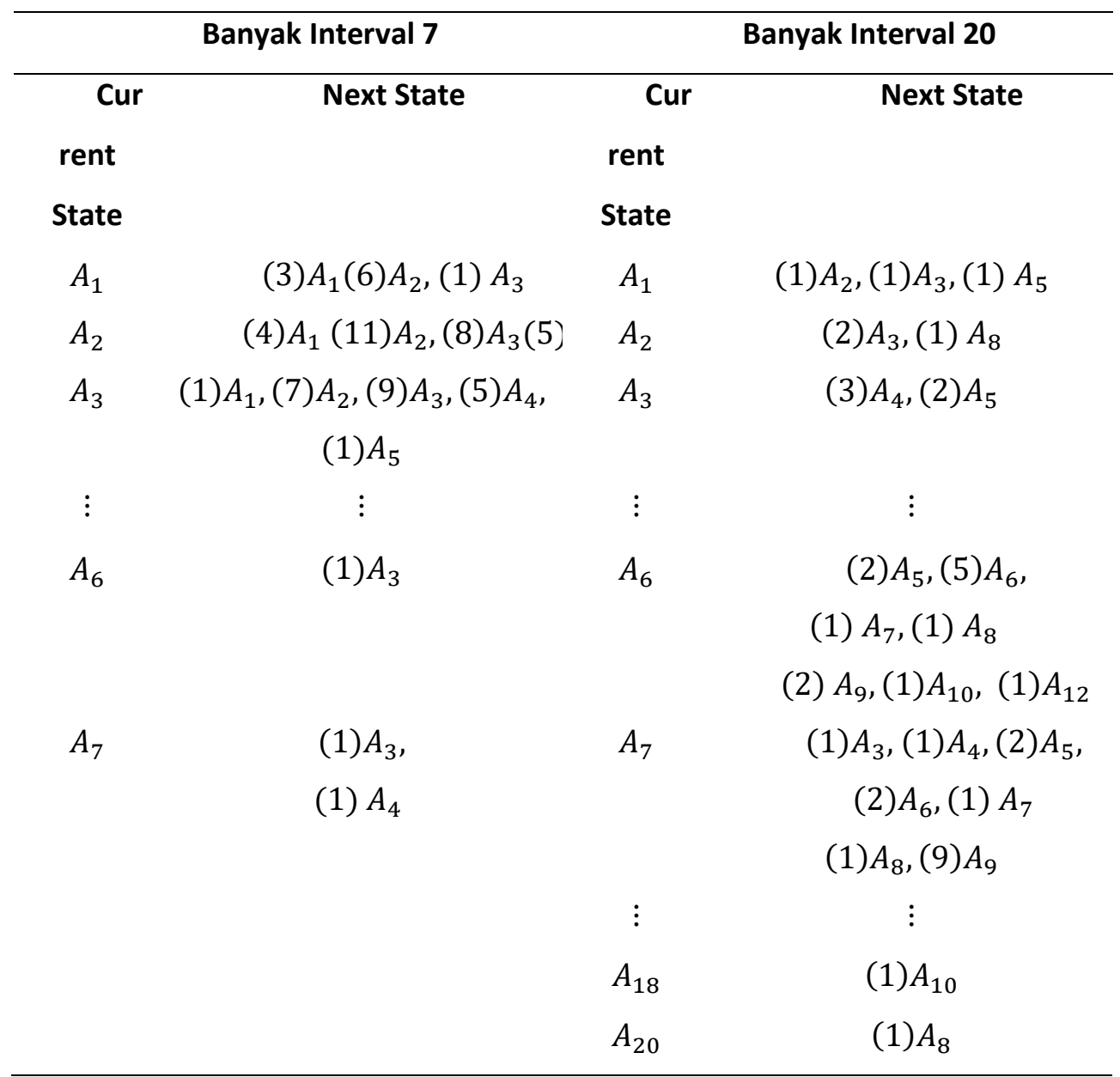

6) Menentukan Model Peramalan

Berdasarkan Tabel 3, dapat diperoleh matriks probabilitas transisi $R$ sebagai berikut Banyak interval 7

$R=\left[\frac{3}{10} \frac{6}{10} \frac{1}{10} 0000 \frac{4}{28} \frac{11}{28} \frac{8}{28} \frac{5}{28} 000 \frac{1}{23} \frac{7}{23} \frac{9}{23} \frac{5}{23} \frac{1}{23} 00 \frac{1}{16} \frac{2}{16} \frac{4}{16} \frac{5}{16} \frac{3}{16} \frac{1}{16} 00 \frac{2}{4} 00000 \frac{2}{4} 0010000000 \frac{1}{2} \frac{1}{2} 0000\right]$ 
Banyak interval 20

Kolom
$R-7$
$R=\left[\begin{array}{ccccccc}0 & 1 / 3 & 1 / 3 & 0 & 1 / 3 & 0 & 0 \\ 0 & 0 & 2 / 3 & 0 & 0 & 0 & 0 \\ 0 & 0 & 0 & 3 / 5 & 2 / 5 & 0 & 0 \\ 1 / 7 & 1 / 7 & 0 & 1 / 7 & 2 / 7 & 1 / 7 & 1 / 7 \\ 0 & 1 / 13 & 1 / 13 & 2 / 13 & 2 / 13 & 1 / 13 & 3 / 13 \\ 0 & 0 & 0 & 0 & 2 / 13 & 5 / 13 & 1 / 13 \\ 0 & 0 & 1 / 10 & 1 / 10 & 2 / 10 & 2 / 10 & 1 / 10 \\ 0 & 0 & 0 & 0 & 0 & 1 / 5 & 0 \\ 1 / 8 & 0 & 0 & 0 & 1 / 8 & 1 / 8 & 3 / 8 \\ 0 & 0 & 0 & 0 & 0 & 0 & 1 / 4 \\ 0 & 0 & 0 & 0 & 0 & 1 / 5 & 0 \\ 0 & 0 & 0 & 0 & 0 & 0 & 0 \\ 0 & 0 & 0 & 0 & 1 / 3 & 1 / 3 & 0 \\ 0 & 0 & 0 & 0 & 0 & 0 & 0 \\ 0 & 0 & 0 & 0 & 0 & 0 & 0 \\ 0 & 0 & 0 & 0 & 0 & 0 & 0 \\ 0 & 0 & 0 & 0 & 0 & 0 & 0 \\ 0 & 0 & 0 & 0 & 0 & 0 & 0 \\ 0 & 0 & 0 & 0 & 0 & 0 & 0 \\ 0 & 0 & 0 & 0 & 0 & 0 & 0\end{array}\right.$

Kolom 8-14

$\begin{array}{ccccccc}0 & 0 & 0 & 0 & 0 & 0 & 0 \\ 1 / 3 & 0 & 0 & 0 & 0 & 0 & 0 \\ 0 & 0 & 0 & 0 & 0 & 0 & 0 \\ 0 & 0 & 0 & 0 & 0 & 0 & 0 \\ 0 & 0 & 2 / 13 & 1 / 13 & 0 & 0 & 0 \\ 1 / 13 & 2 / 13 & 1 / 13 & 0 & 1 / 13 & 0 & 0 \\ 1 / 10 & 2 / 10 & 0 & 0 & 0 & 0 & 0 \\ 1 / 5 & 1 / 5 & 0 & 1 / 5 & 0 & 0 & 0 \\ 0 & 1 / 8 & 0 & 1 / 8 & 0 & 0 & 0 \\ 0 & 2 / 4 & 0 & 0 & 0 & 1 / 4 & 0 \\ 0 & 0 & 0 & 2 / 5 & 0 & 1 / 5 & 0 \\ 0 & 0 & 0 & 0 & 0 & 1 & 0 \\ 0 & 0 & 0 & 0 & 0 & 0 & 0 \\ 0 & 0 & 0 & 0 & 0 & 0 & 0 \\ 0 & 0 & 0 & 0 & 0 & 0 & 0 \\ 1 & 0 & 0 & 0 & 0 & 0 & 0 \\ 0 & 0 & 0 & 0 & 0 & 0 & 0 \\ 0 & 0 & 1 & 0 & 0 & 0 & 0 \\ 0 & 0 & 0 & 0 & 0 & 0 & 0 \\ 1 & 0 & 0 & 0 & 0 & 0 & 0\end{array}$

Kolom $15-20$

$\left.\begin{array}{cccccc}0 & 0 & 0 & 0 & 0 & 0 \\ 0 & 0 & 0 & 0 & 0 & 0 \\ 0 & 0 & 0 & 0 & 0 & 0 \\ 0 & 0 & 0 & 0 & 0 & 0 \\ 0 & 0 & 0 & 0 & 0 & 0 \\ 0 & 0 & 0 & 0 & 0 & 0 \\ 0 & 0 & 0 & 0 & 0 & 0 \\ 1 / 5 & 0 & 0 & 0 & 0 & 0 \\ 0 & 0 & 0 & 0 & 0 & 0 \\ 0 & 0 & 0 & 0 & 0 & 0 \\ 0 & 1 / 5 & 0 & 0 & 0 & 0 \\ 0 & 0 & 0 & 0 & 0 & 0 \\ 0 & 0 & 0 & 0 & 0 & 1 / 3 \\ 0 & 0 & 0 & 0 & 0 & 0 \\ 0 & 0 & 0 & 1 & 0 & 0 \\ 0 & 0 & 0 & 0 & 0 & 0 \\ 0 & 0 & 0 & 0 & 0 & 0 \\ 0 & 0 & 0 & 0 & 0 & 0 \\ 0 & 0 & 0 & 0 & 0 & 0 \\ 0 & 0 & 0 & 0 & 0 & 0\end{array}\right]$

7) Menghitung nilai peramalan

Untuk menguji model yang telah diperoleh dari langkah sebelumnya, maka model tersebut diuji pada 23 data uji.

Peramalan untuk bulan Februari 2017.

\section{Banyak interval 7}

Perhatikan bahwa pada bulan Januari 2017 berada pada state $A_{3}$. Perhatikan matriks transisi $R$ pada baris ke-3, maka peramalan

$$
\begin{gathered}
F(t)=m_{1} P_{31}+m_{2} P_{32}+Y(t-1) P_{33}+m_{4} P_{34}+\cdots+m_{7} P_{37} \\
F(t)=14506 \cdot \frac{1}{23}+17358 \cdot \frac{7}{23}+20554 \cdot \frac{9}{23}+23062 \cdot \frac{5}{23}+25914 \cdot \frac{1}{23}+0+0=20096.6
\end{gathered}
$$

\section{Banyak interval 20}

Karena bulan Januari 2017 state berada di $A_{8}$ maka perhatikan baris ke-8 pada matriks transisi R. Perhitungan peramalan sebagai berikut :

$$
\begin{gathered}
F(t)=m_{1} P_{81}+\cdots+m_{7} P_{87}+Y(t-1) P_{88}+m_{9} P_{89}+\cdots+m_{20} P_{820} \\
F(t)=0+0+0+0+0+18600 \cdot \frac{1}{5}+0+20554 \cdot \frac{1}{5}+21600 \cdot \frac{1}{5}+0+23600 \cdot \frac{1}{5}+0+0+0+27600 \\
\cdot \frac{1}{5}+0+0+0+0+0=22390.8
\end{gathered}
$$

8) Menghitung nilai penyesuaian.

\section{Banyak Interval 7}

Peramalan pertama di bulan Februari 2017 terjadi transisi state $A_{3} \rightarrow A_{2}$.

Penyesuaian $=-\left(\frac{l}{2}\right)=-\left(\frac{2852}{2}\right)=-1426$

\section{Banyak Interval 20}

Peramalan pertama, yaitu bulan Februari 2017 terjadi transisi state $A_{8} \rightarrow A_{5}$.

Penyesuaian $=-\left(\frac{l}{2}\right) \cdot 3=-\left(\frac{1000}{2}\right) \cdot 3=-1500$

9) Menghitung Nilai Peramalan Akhir.

Banyak interval $7: F^{\prime}(t)=20096.6-1426=18670.6$

Banyak interval $20: F^{\prime}(t)=22390.8-1500=20890.8$ 
Nilai peramalan akhir secara lengkap untuk 23 data uji dapat dilihat pada Tabel 4 dan Tabel 5

Tabel 4. Nilai Peramalan dengan banyak interval 7

\begin{tabular}{|c|c|c|c|c|c|}
\hline \multirow[t]{2}{*}{ Bulan } & \multicolumn{2}{|l|}{ Data } & \multicolumn{2}{|c|}{ Peramalan } & \multirow[b]{2}{*}{ Error } \\
\hline & Aktual & Peramalan & Penyesuaian & $\begin{array}{l}\text { Peramalan setelah } \\
\text { penyesuaian }\end{array}$ & \\
\hline Februari 2017 & 17301 & 20096.61 & -1426 & 18670.61 & 1369.61 \\
\hline Maret & 22781 & 18761.61 & 2852 & 21613.61 & 1167.39 \\
\hline April & 21391 & 21904.69 & -1426 & 20478.69 & 912.31 \\
\hline$\vdots$ & $\vdots$ & $\vdots$ & $\vdots$ & $\vdots$ & $\vdots$ \\
\hline November 2018 & 22737 & 18301.57 & 2852 & 21153.57 & 1583.43 \\
\hline Desember & 21787 & 21890.94 & 0 & 21890.94 & 103.94 \\
\hline
\end{tabular}

Tabel 5. Nilai Peramalan dengan banyak interval 20

\begin{tabular}{|c|c|c|c|c|c|}
\hline \multirow{2}{*}{ Bulan } & \multirow{2}{*}{$\begin{array}{l}\text { Data } \\
\text { Aktual }\end{array}$} & \multicolumn{4}{|c|}{ Peramalan } \\
\hline & & Peramalan & Penyesuaian & $\begin{array}{l}\text { Peramalan setelah } \\
\text { penyesuaian }\end{array}$ & Error \\
\hline Februari 2017 & 17301 & 22390.80 & -1500 & 20890.80 & 3589.80 \\
\hline Maret & 22781 & 18784.77 & 2500 & 21284.77 & 1496.23 \\
\hline April & 21391 & 20850.00 & -500 & 20350.00 & 1041 \\
\hline$\vdots$ & $\vdots$ & $\vdots$ & $\vdots$ & $\vdots$ & $\vdots$ \\
\hline Nov & 22737 & 16818.57 & 3000 & 19818.57 & 2918.42 \\
\hline Des & 21787 & 20850.00 & -500 & 20350.00 & 1437 \\
\hline
\end{tabular}

Selanjutnya, pada Gambar 2 ditampilkan perbandingan grafik antara data aktual dengan nilai peramalan

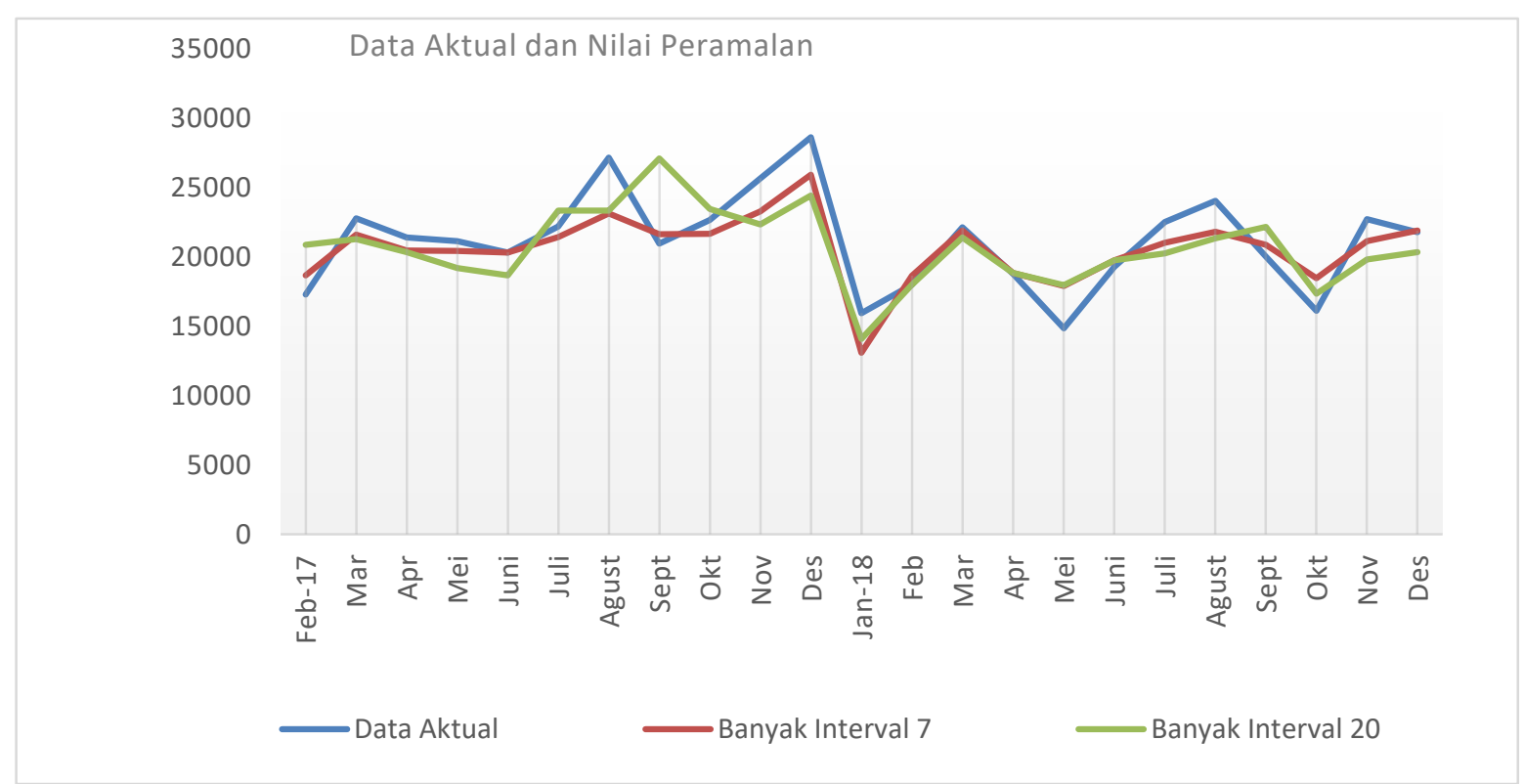

Gambar 2. Perbandingan Grafik Data Aktual dan Nilai Peramalan

10) Menentukan Tingkat Akurasi Peramalan

Gambar 2 menyajikan perbandingan grafik dari data aktual bulan Februari 2017 sampai Desember 2018 dengan nilai peramalan. Secara Umum dapat dilihat bahwa grafik hampir 
berhimpitan yang artinya nilai peramalan hampir mendekati nilai aktual. Tingkat akurasi peramalan yang dihitung menggunakan MAPE diperoleh dengan banyak interval 7 , MAPE adalah $6.66 \%$ dan banyak interval 20, MAPE adalah $9.87 \%$.

\section{Peramalan Jumlah Wisatawan Mancanegara Yang Datang Ke Sumatera Utara Tahun 2019}

Berdasarkan hasil pengujian akurasi peramalan, MAPE dengan banyak interval 7 lebih kecil dibandingkan dengan banyak interval 20 . Oleh sebab itu, peramalan jumlah wisatawan mancanegara yang datang ke Sumatera Utara untuk tahun 2019 menggunakan model matriks transisi $R$ pada banyak interval 7. Peramalan untuk bulan Januari 2019 menggunakan data aktual bulan Desember 2018 sebagai data input. Sedangkan untuk bulan-bulan yang lain, nilai peramalan menjadi data input untuk peramalan bulan-bulan berikutnya.

Tabel 6. Peramalan untuk Tahun 2019

\begin{tabular}{cc}
\hline Bulan & Peramalan \\
\hline Januari 2019 & 21594.0625 \\
Februari & 20503.58967 \\
Maret & 20076.88292 \\
April & 19909.91071 \\
Mei & 19844.57375 \\
Juni & 19819.00712 \\
Juli & 19809.00279 \\
Agustus & 19805.08805 \\
September & 19803.55619 \\
Oktober & 19802.95677 \\
November & 19802.72221 \\
Desember 2019 & 19802.63043 \\
\hline
\end{tabular}

Tabel 6 Menunjukan hasil peramalan pada bulan-bulan di tahun 2019. Nilai peramalan menunjukan tren yang menurun dengan selisih sangat kecil dan cenderung tetap mulai bulan Oktober 2019. Jika melihat nilai rata-rata dari 108 data aktual, yaitu sebesar 19974,9 maka nilai error peramalan dibandingkan rata-rata sangat kecil yaitu sebesar $0,5 \%$.

\section{Kesimpulan}

Berdasarkan hasil penelitian, metode fuzzy time series dapat diimplementasikan dalam peramalan jumlah wisatawan yang datang ke Sumatera Utara. Penggunaan rumus Sturges pada himpunan semesta menghasilkan 7 buah interval dan rumus average based length menghasilkan 20 buah interval. Hasil peramalan dengan metode Fuzzy Time Series Markov Chain dengan banyak interval 7, MAPE 6,66 \% lebih akurat daripada banyak interval 20, MAPE 9,87 \%. Nilai ramalan pada bulan Januari 2019 sebesar 21594,0625 dan mengalami tren menurun dengan selisih sangat kecil untuk bulan-bulan selanjutnya. 


\section{Daftar pustaka}

[1] Spillane, James, J, "Ekonomi Pariwisata, Sejarah dan Prospeknya", Kanisius, Yogyakarta, 1987

[2] Buffa, S., et al, "Modern Production and Operation Management. Eight Edition", Jhon Willey and Sons Inc, London, 1996

[3] Hakimi, F. D.D.,dkk, "Peramalan Kecepatan Angin yang Direkamoleh Sistem AWS dengan Analisis Fuzzy Time Series", Jurnal Publikasi Ilmiah Matematika Vol. 2 No. 2, pp. 24-32, 2017

[4] Windasari, wahyuni, "Peramalan Harga Saham Kioson di Era Ekonomi Digital", Jurnal Publikasi IImiah Matematika Vol. 3 No. 1, pp. 77-82, 2018

[5] Cahyandari, R dan R. Erviana, "Peramalan Kurs Jual Uang Kertas Mata Uang Singapore Dollar (SGD) terhadap Rupiah Menggunakan Model ARFIMA (Autoregressive Fractionally Integrated Moving Average)", Jurnal Publikasi Ilmiah Matematika Vol. 1 No. 1, pp. 49-58, 2015.

[6] Song, Q dan Chissom, B, "Forecasting Enrollments with Fuzzy Time Series-Part I", International Journal of Fuzzy Sets and Systems 54:1-9, 1993

[7] Chen, S. M, "Forecasting Enrollments based on Fuzzy Time Series. Fuzzy Sets and Systems", International Journal of Applied Science and Engineering, 1996

[8] Elfajar, Aria B., dkk, "Peramalan Jumlah Kunjungan Wisatawan Kota Batu Menggunakan Metode Time Invariant Fuzzy Time Series", Jurnal Pengembangan Teknologi dan IImu Komputer, Vol 1 No. 2, pp. 85-94, 2017

[9] Gamalita ,A., dkk, "Analisis dan Perancangan Aplikasi Web Prediksi Indeks Harga Saham Gabungan menggunakan Fuzzy Time Series Markov Chain Model [Skripsi]", Universitas Bina Nusantara, Jakarta, 2014

[10] Rukhansah, Nurmalia., dkk, "Peramalan harga emas menggunakan Fuzzy Time Series Markov Chain Model", KOMPUTAKI Vol 1 No. 1, pp. 56-74, 2015

[11] Tsaur, RC. 2012. A Fuzzy Time Series-Markov Chain Model With An Application to Forecast The Exchange Rate Between Taiwan and US Dollar. International Journal of Innovative Computing, Information and Control. 87(B) 2012 : 4931-4942. 